DOI: https://doi.org/10.34883/PI.2021.9.3.010

UDC 616-056.7:616-008.9:546.56

Berezenko V., Proshchenko Ju., Krat V., Diba M., Mykhailiuk Kh., Tkalik E.

Bogomolets National Medical University, Kyiv, Ukraine

Березенко В.С., Прощенко Ю.И., Крат В.В., Дыба М.Б., Михайлюк К.З., Ткалик Е.Н.

Национальный медицинский университет имени А.А. Богомольца, Киев, Украина

\title{
Wilson's Disease in Children. Case Report
}

\author{
Болезнь Вильсона у детей. Клинический случай
}

\begin{abstract}
Wilson's disease is the disease, the course and clinical picture of which varies from asymptomatic forms to severe manifestations of dysfunction of many organs and systems and the diagnosis requires a multidisciplinary approach. The disease usually manifests itself with liver damage, which can occur in children older than 2 years with such pathological conditions as acute hepatitis, hepatomegaly, hepatic steatosis, acute hepatic failure with hemolysis, portal hypertension, and even decompensated liver cirrhosis with ascites. Early diagnostics and timely treatment prevent disease progression and disability of the patient. The main methods of diagnosing Wilson's disease are the biochemical determination of copper metabolism (serum ceruloplasmin and daily excretion of copper in the urine), molecular genetic research, and puncture biopsy of the liver with the study of copper concentration in liver parenchyma. Nowadays, Wilson's disease is treated with drugs that are able to block the absorption of copper in the intestine (zinc salts) and drugs that bind and remove excess copper from the body - D-penicillamine, Trientin.
\end{abstract}

Keywords: Wilson's disease, cupper, hepatitis, ceruloplasmin, liver biopsy.

\section{Резюме}

Болезнь Вильсона - это заболевание, течение и клиническая картина которого варьируется от бессимптомных форм до тяжелых проявлений дисфункции многих органов и систем, диагностика которого требует мультидисциплинарного подхода. В большинстве случаев заболевание проявляется поражением печени, которое может возникать у детей старше 2 лет с такими патологическими состояниями, как острый гепатит, гепатомегалия, стеатоз печени, острая печеночная недостаточность с гемолизом, портальная гипертензия и даже декомпенсированный цирроз печени с асцитом. Ранняя диагностика и своевременно назначенная терапия предотвращают прогрессирование заболевания и инвалидизацию пациента. Основными методами диагностики болезни Вильсона являются биохимическое определение метаболизма меди (сывороточный церулоплазмин и суточная экскреция меди с мочой), молекулярногенетическое исследование и пункционная биопсия печени с исследованием концентрации меди в паренхиме печени. В настоящее время болезнь Вильсона лечат препаратами, которые способны блокировать всасывание меди в кишечнике (соли цинка), и препаратами, связывающими и выводящими излишки меди из организма - D-пеницилламином, триентином.

Ключевые слова: болезнь Вильсона, медь, гепатит, церулоплазмин, биопсия печени. 


\section{- INTRODUCTION}

Wilson's disease (WD) is a hereditary autosomal recessive disease that is associated with impaired copper metabolism and accumulation in organs and tissues with predominant damage to the liver and central nervous system. The prevalence of WD in the population ranges from $1: 30000$ to $1: 100000$ with a heterozygous carrier frequency of the pathological gene of 1 : 90. (Golovanova E., Lazebnik L., etc.). WD is a difficult-to-diagnose liver disease associated with a long latent course, especially in the initial stages of the disease and a large polymorphism of clinical symptoms, and therefore this disease should be excluded in any child with an unspecified etiology of the liver. Timely initiated pathogenetic therapy promotes regression of clinical symptoms, prevents the formation of cirrhosis of the liver and neurological disorders, improves the quality of life and social adaptation of the child $[1,2,8,13,14]$.

WD is due to the presence of the pathological gene ATP7B localized on the long arm of the 13 chromosome (13q14.3-q21.1). Nowadays, about 500 mutations of the ATP7B gene are known, 380 of which are identified as factors for the development of the disease $[4,15]$. ATP7B gene expression predominantly occurs in the liver, and its main function is to encode coppertransporting ATPase. A genetically determined decrease in the function of copper-transporting ATPase leads to a decrease in hepatobiliary copper excretion and its binding to ceruloplasmin and accumulation in organs and tissues of the body (mainly in the liver, brain, kidneys, iris), accompanied by appropriate clinical symptoms $[1,2,8,13]$.

The pathogenetic mechanisms of WD are related to the influence of excess copper on the formation of free radicals, which deplete the reserves of glutathione and tocopherol in cells, oxidize lipids, enzymes and proteins of the cytoskeleton. In the early stages of hepatocellular damage there is an involvement in the pathological process of such important cellular organelles as endoplasmatic reticulum, mitochondria, peroxisomes and nucleoli, which combined with reduced activity of mitochondrial enzymes, leads to lipids peroxide oxidation and accumulation of triglycerids and, as a consequence, to necrosis of hepatocytes. In the process of lipid peroxidation, malonic aldehyde is formed, which accelerates collagen synthesis and promotes fibrogenesis. The decay of hepatocytes leads to an increase in the level of free copper in the serum, and, accordingly, a compensatory increase in its daily excretion with urine and its accumulation in the target organs [1, $2,8,13]$.

Classification of WD is based on clinical signs of the disease, according to which the following forms are distinguished: asymptomatic, hepatic, cerebral and mixed. The clinical manifestation of WD is very diverse. Usually, the disease manifests with liver damage, which can occur in children older than 2 years with such pathological conditions as acute hepatitis, hepatomegaly, hepatic steatosis, acute hepatic failure with hemolysis, portal hypertension and even decompensated liver cirrhosis with ascites. It should be noted that often WD is diagnosed after accidentally detected elevated liver transaminases. Neurological and psychiatric disorders in WD are usually registered in children older than 15 years (although neurological disorders are described in children aged 7-9 years) and include: dysarthria, dysphagia, exessive salivation, behavioral disorders, including depression, 
irritability; tremor; mask-like face; Gait disorders, dystonia, rigidity, Stroke-like symptoms. In some children older than 10, ophthalmologists record the presence of Kayser-Fleischer rings on the descemet's cornea of the eye and, sometimes, copper cataract. Renal manifestations of WD include: renal tubular dysfunction (Fanconi syndrome, tubular acidosis, aminoaciduria); nephrocalcinosis and nephrolithiasis. In addition, there may be cardiac manifestations of the disease (cardiomyopathy and arrhythmia); hematological (acute and chronic hemolytic anemia); endocrinological (hypoparathyroidism) and others (pancreatitis, rickets and arthropathy) [2, $5,6,8]$.

Diagnosis of WD includes liver function tests, examination of serum ceruloplasmin level, determination of serum copper level and urinary copper excretion, molecular genetic testing and liver biopsy with determination of copper concentration in liver tissue [7, 8].

For children with Wilson's disease pathological changes in hepatic samples in a biochemical blood test (increased total bilirubin, transaminases, decreased alkaline phosphatase) are typical. It should be noted that these changes are not specific to Wilson's disease only and may be present in other liver diseases $[7,8]$.

Ceruloplasmin is a specific protein that in healthy persons $90 \%$ ensures the removal of copper from the body. Non-copper-bound ceruloplasmin is excreted twice as fast as bound, and therefore hypoceruloplasminemia may occur in patients with WD. Also the level of ceruloplasmin in the serum is reduced in newborns, and with age its concentration in the serum gradually increases. Therefore, determining its level is informative for diagnosis only in children after 1 year. Besides, concentration of ceruloplasmin in serum of blood may be reduced physiologically in adolescents and at such diseases as an acute liver failure, malabsorption, Menkes disease, protein-energy malnutrition, nephrotic syndrome, congenital aceruloplasminemia and others. The recommended diagnostic threshold for ceruloplasmin in Wilson's disease according to ESPGHAN and NASPGHAN is $14 \mathrm{mg} / \mathrm{dL}$ (sensitivity 93\%, specificity $100 \%$ ). With a serum ceruloplasmin concentration of $20 \mathrm{mg} / \mathrm{dL}$, sensitivity is $95 \%$, and specificity is $84.5 \%$, which should be taken into account when conducting diagnostics. Literature data indicate that in $20 \%$ of patients with Wilson's disease serum ceruloplasmin levels may be within normal limits, and may even be elevated in histologically active chronic hepatitis and in pregnant women $[8,11]$.

Study of copper concentration in blood serum is not used for diagnosis of Wilson's disease, but is informative enough for carrying out control of pharmacotherapy $[4,10,11]$.

Determination of daily copper excretion is one of the main diagnostic tests in suspected Wilson's disease. It should be noted that in asymptomatic and moderate forms, daily urinary copper excretion may be within normal limits. The diagnostic threshold for urinary copper excretion according to ESPGHAN and NASPGHAN is $40 \mu \mathrm{g} /$ day $(0.65 \mu \mathrm{mol} /$ day $)$ in this case, the sensitivity and specificity of the test is $78.9 \%$ and $87.9 \%$, respectively. The study of copper concentration after loading with D-penicylamine is an unreliable method of diagnosing asymptomatic forms of Wilson's disease, the sensitivity is only $12-46 \%$ [8-11]. 
Molecular genetic testing and liver biopsy are crucial in the diagnosis of WD. Specific gene mutations specific of certain populations have been established: for example, in Eastern Europe - H1069Q, Spain - Met645Arg, Japan - 229insC, in China, Korea and Taiwan - Arg778Leu [4, 14, 15]. Performing liver biopsy with determination of copper concentration in liver parenchyma is an important method in the diagnosis of Wilson's disease. The concentration of copper in the liver parenchyma $>250 \mathrm{mg} / \mathrm{g}$ (normal $<50 \mathrm{mg} / \mathrm{g}$ ) in the absence of cholestasis is characteristic of CF. It should be pointed that the copper content in the liver parenchyma in WD is usually higher in patients with hepatic impairment than in patients with asymptomatic forms and in patients with neurological disorders without liver damage. Hepatic form of WD is accompanied by concentration of copper in the liver parenchyma $>250 \mathrm{mg} / \mathrm{g}$. In addition, it should be noted that the concentration of copper may increase in diseases such as primary biliary cirrhosis and primary sclerosing cholangitis $[8,11]$.

In accordance with the recommendations of ESPGHAN and NASPGHAN in case of suspected CF the following diagnostic algorithm should be used:

Step 1 includes a clinical examination (presence of hepatosplenomegaly, ascites, Kayser-Fleischer ring); study of liver samples (ALT/AST, total and direct bilirubin, alkaline phosphatase); biochemical determination of copper metabolism in the body (serum ceruloplasmin and daily excretion of copper in the urine).

Step 2 involves genetic testing.

Step 3 - performing a liver biopsy to determine the concentration of copper inside.

After carrying out the above complex in accordance with these recommendations, a diagnostic scale is used in which the sum of the scores can establish a probable diagnosis of WD in a child (Table).

Today, Wilson's disease is treated with drugs that are able to block the absorption of copper in the intestine (zinc salts) and drugs that bind

\section{Diagnostic scale of WD [5]}

\begin{tabular}{|c|c|c|c|c|c|}
\hline & -1 & 0 & 1 & 2 & 4 \\
\hline Kayser-Fleischer rings & & Absent & & Present & \\
\hline $\begin{array}{l}\text { Neurological and psychiatric } \\
\text { symptoms associated with WD (typical } \\
\text { signs of MRI) }\end{array}$ & & Absent & & Present & \\
\hline $\begin{array}{l}\text { Hemolytic anemia (Coombs-) + } \\
\text { elevated serum copper }\end{array}$ & & Absent & Present & & \\
\hline $\begin{array}{l}\text { Excretion of copper in the urine (in the } \\
\text { absence of active hepatitis) }\end{array}$ & & Absent & $\begin{array}{l}\text { Present } \\
1-2 \mathrm{~N}\end{array}$ & $\begin{array}{l}>2 \mathrm{~N} \text { or within normal } \\
\text { limits }+>5 \mathrm{~N} \text { after } \\
\text { challenge with } \\
\text { D-penicillamine }\end{array}$ & \\
\hline $\begin{array}{l}\text { The concentration of copper in the } \\
\text { liver biopsy }\end{array}$ & Norm & & $\begin{array}{l}<5 \mathrm{~N} \\
(<250 \mathrm{mg} / \mathrm{g})\end{array}$ & $>5 \mathrm{~N}(>250 \mathrm{mg} / \mathrm{g})$ & \\
\hline Rhodanine test & & Negative & Positive & & \\
\hline Serum ceruloplasmin & & $>0.2 \mathrm{~g} / \mathrm{l}$ & $0.1-0.2 \mathrm{~g} / \mathrm{l}$ & $<0.1 \mathrm{~g} / \mathrm{l}$ & \\
\hline Disease-causing mutations detected & & None & One & & Two \\
\hline
\end{tabular}

Note:

Score on a scale: $0-1$ point - the diagnosis of WD is unlikely; $2-3$ points - probable; 4 or more points - highly likely. 
and remove excess copper from the body - D-penicillamine, Trientin (not registered in Ukraine). The choice of drug depends on the form of the lesion. Zinc salts (zinc sulfate and zinc acetate) are used as drugs of choice in asymptomatic forms of the disease, and are prescribed in combination therapy with D-penicillamine in other forms of WD at the beginning of treatment to remove excess copper from the intestine. It should be noted that zinc preparations have less side effects compared to D-penicillamine and are better tolerated by patients, have a detoxification effect. Monotherapy with zinc preparations in patients with hepatic, cerebral or mixed forms is not recommended. Prescribing in WD D-penicylamine has an expressive therapeutic effect and promotes the regression of hepatic lesions at $80 \%$ over 16 months $[3,7,8,12]$.

A significant place in the treatment of WD is a diet, because copper enters the human body mainly with food. The daily requirement of copper in a healthy person is $2-4 \mathrm{mg} /$ day (maximum allowable level $-5 \mathrm{mg}$ ). Copper deficiency occurs when the body enters less than $1 \mathrm{mg} /$ day. Patients with WD are advised to limit the consumption of high-copper foods for life (liver, seafood, cocoa, nuts (especially hazelnuts), seeds, cucumbers, rose hips, cheese, chocolate, mushrooms, legumes, buckwheat, strawberries, gooseberries). The main foods for Wilson's disease should be eggs, potatoes, various types of cabbage, zucchini, dairy products and oil. In addition, when drawing up a diet plan, attention should be paid to products that contain copper antagonists. Copper antagonists in the human body are zinc, molybdenum, iron and vitamin C $[3,7,12]$.

\section{- CLINICAL CASE REPORT}

A boy $(\mathrm{Y}), 7$ years old, was born from the second pregnancy and the second birth, which occurred without complications. In the first year of life, physical and neuropsychological development corresponded to age. Transferred diseases: acute respiratory viral infections 2-3 times / year, chickenpox. At the age of 6 year 9 months, the child suddenly had complaints of nausea and vomiting, which was regarded as food poisoning. When performing laboratory tests, revealed: increased levels of transaminases (ALT-291 o/l, AST - 157 o/l, GGT-59). ANA 1: 320, lgG - 11.0, ESR - 14 mm per hour. The level of ceruloplasmin in the serum is within normal limits. Infection with viral hepatitis (HBV, HAV, HCV) is excluded. With a diagnosis of cryptogenic hepatitis, the child was admitted to the Pediatric Hepatology center of the Institution of pediatrics, obstetrics and gynecology named after Academician OM Lukyanova of the National Academy of Medical Sciences of Ukraine.

Upon admission, the child had abdominal pain and numbness of the fingers of the left hand. Physical development is average, harmonious. During an objective examination, it was established: integuments pale with a gray shade, periorbital cyanosis is noted. Visible mucous membranes are pale, clean. The pulmonary tone is percutaneously clear over the lungs, vesicular breathing. The boundaries of the heart were percutaneously consistent with the age of the child. Heart tones are auscultally sounding, arrhythmic. The abdomen is of the correct shape, takes part in the act of breathing, symmetrical, not enlarged, soft, sensitive in the epigastrium. Sections of the large intestine are available for deep palpation, not painful. 
Liver: surface: smooth; the edge is smooth, palpably the edge of the liver is painless, elastic consistency, protrudes from under the edge of the costal arch by $1 \mathrm{~cm}$. Liver dimensions according to Kurlov: 8,9 and $10 \mathrm{~cm}$, respectively. The spleen is not enlarged. Bladder symptoms (Kerr, Ortner, Murphy, St. George-Musi) are negative. The kidneys are not accessible to palpation, Pasternatsky's symptom is negative on both sides. Diuresis is sufficient, urine is straw-yellow. Stools are regular, with usual calor, without pathological impurities. Peripheral edema is absent. During the examination, the boy is mobile, active and passive movements in full. No muscle tone and strength disorders revealed.

The patient underwent laboratory and instrumental examination. According to the results of a biochemical blood test: bilirubin $-11 \mu \mathrm{mol} / \mathrm{l}$ (direct - $4 \mu \mathrm{mol} / \mathrm{l}$, indirect - $7 \mu \mathrm{mol} / \mathrm{l}$ ), alkaline phosphatase - $300 \mathrm{U} / \mathrm{l}$ (normal - <644 U/l), total protein - 68/l (norm 65-85 g/l), GGT $52 \mathrm{U} / \mathrm{l}$ (norm - <23 U/I), ALT - $299 \mathrm{U} / \mathrm{I}$ (norm to $41 \mathrm{U} / \mathrm{l}$ ), AST - $180 \mathrm{U} / \mathrm{I}$ (norm) up to $37 \mathrm{IU} / \mathrm{I})$. Violation of the lipid profile and hemostasis was not detected. The concentration of 25 -hydroxyvitamin $D$ is $46.7 \mathrm{nmol} / \mathrm{l}$ ( $<50$ deficiency). Daily excretion of copper in the urine is within normal limits. Test with kuprenil (1000 mg) - $1147 \mu \mathrm{g} / 24 \mathrm{~h}$ (which was more than 5 norms -2 points). The level of ceruloplasmin in the blood serum was $13.9 \mathrm{mg} / \mathrm{dl}$ (norm 20-35 mg/ dl) -1 point.
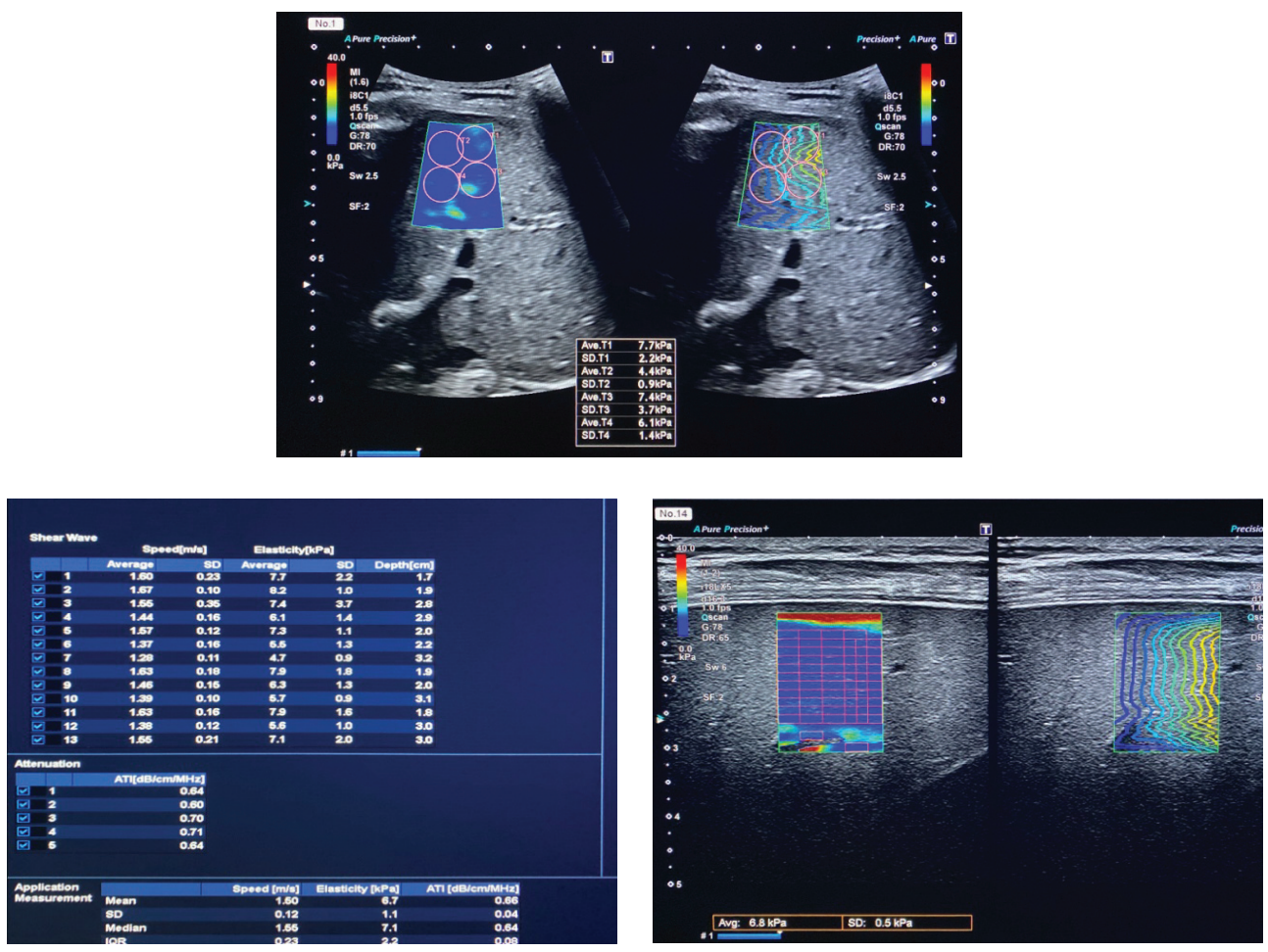

Fig. 1. Elastography of the liver parenchyma of a patient with Wilson's disease by the method of shear wave 

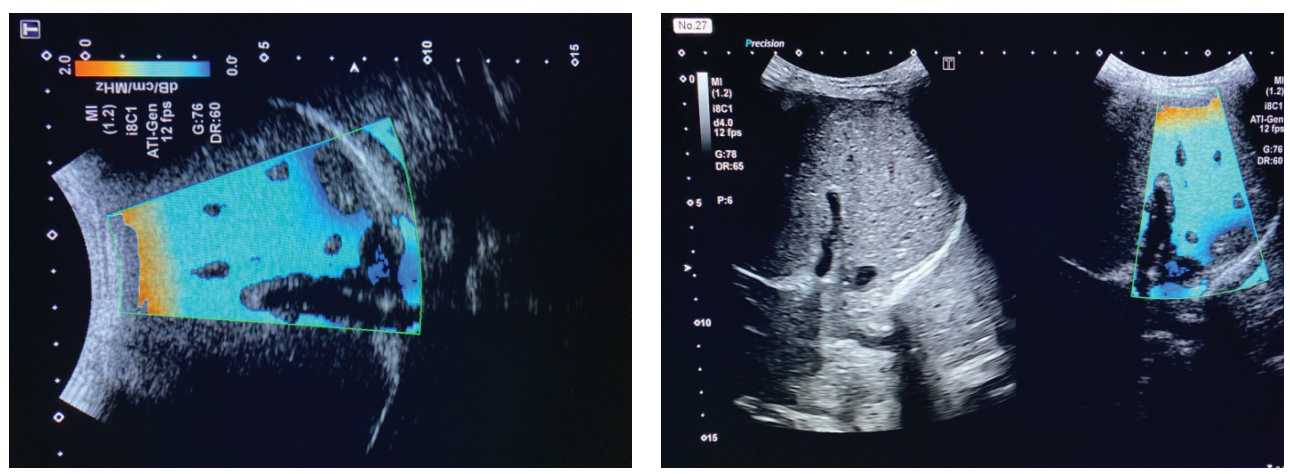

Fig. 2. Steatometry of the liver parenchyma (Liver Attenuation Index) of a patient with Wilson's disease

During an ultrasound examination of the abdominal cavity, ultrasound signs of diffuse changes in the liver parenchyma, spleen, reactive changes in pancreatic tissue were found. No pathology was detected during electrocardiography and esophagogastroduodenoscopy. On the elastography of the shear wave liver parenchyma were found: median liver stiffness $=6.7 \mathrm{kPa}$ at a quarterly interval of $1.0 \mathrm{kPa}$ (which corresponds to a minimal increase in liver stiffness stage F1-F2 by METAVIR) (Fig. 1). Liver parenchyma steatometry (Liver Attenuation Index) $-0.66 \mathrm{db} / \mathrm{cm} /$ $\mathrm{MHZ}$ (corresponding to grade 1 steatosis - S1) (Fig. 2). According to R-densitometry of the lumbar spine and proximal thighs, an indicator of bone mineral density within the age norm.

When performing MRI of the brain, focal and volumetric changes in the brain were not detected ( 0 points). No Kaiser-Fleischer Ring was detected during the examination by an ophthalmologist ( 0 points). In addition, a neurological examination was performed, during which age-appropriate neuropsychological development and the absence of focal neurological symptoms were established.

According to national and international recommendations, the boy underwent a molecular genetic study for Wilson's disease and identified 2 positive pathogenic mutations in the ATP7B gene - p.2304dup (p.Met769Hisfs * 26) - heterozygote, c.3207C > A (p.His1069GIn) - heterozygote (4 points).

When comparing the data with the diagnostic scale of HV, a total of 7 points was obtained, which confirms Wilson's disease in this child.

Final diagnosis: Wilson's disease hepatic form.

Prescribed treatment: dietary nutrition with the exclusion of foods rich in copper. D-penicillamine $20 \mathrm{mg} / \mathrm{kg}$ per day. Vitamin B6 $25 \mathrm{mg} /$ day, ursodeoxycholic acid, vitamin D.

The patient's sibs were conduct a molecular genetic study for Wilson's disease: in the mother - 1 pathogenic mutation in the gene c.3207C> A (p.His1069GIn) - heterozygote, in the father -1 pathogenic mutation in the gene p.2304dup (p.Met769Hisfs * 26) - heterozygote, sister -1 pathogenic mutation in the gene c.3207C > A (p.His1069Gln) - heterozygote. 


\section{- CONCLUSION}

Thus, Wilson's disease is a disease, whose course and clinical picture varies from asymptomatic forms to severe manifestations of dysfunction of many organs and systems and whose diagnosis requires a multidisciplinary approach. Early diagnosis and timely treatment prevents disease progression and disability of the patient. The main methods of diagnosing Wilson's disease are the biochemical determination of copper metabolism (serum ceruloplasmin and daily excretion of copper in the urine), a molecular genetic research and puncture biopsy of the liver with a study of copper concentration in liver parenchyma.

Conflict of interest. The authors declare no conflict of interest.

\section{- REFERENCES}

1. Golovanova E., Lazebnik L. (2015) Bolezn' Vil'sona - Konovalova (gepatocerebral'naya distrofiya, gepatolentikulyarnaya degeneraciya): diagnostika, lechenie i dispansernoe nablyudenie [Wilson - Konovalov's disease (hepatocerebral dystrophy, hepatolenticular degeneration): diagnostics, treatment and dispensary observation]. Eksperimental'naya i i klinicheskaya gastroenterologiya, 119, pp. 108-111. Available at: https://doi.org/10.21518/2079-701X-2013-10-42-45

2. Bandmann O., Weiss K.H., Kaler S.G. (2015) Wilson's disease and other neurological copper disorders. Lancet Neurol, 14, pp. 103-113. doi: 10.1016/ S1474-4422(14)70190-5.

3. Capone K., Azzam R.K. (2018) Wilson's Disease: A Review for the General Pediatrician. Pediatr Ann., 47 (11), pp. 440-444. doi: 10.3928/1938235920181026-01

4. $\quad$ Dong Y., Ni W., Chen W.J., Wan B., Zhao G.X., Shi Z.Q., Zhang Y., Wang N., Yu L., Xu J.F., Wu Z.Y. (2016) Spectrum and classification of ATP7B variants in a large cohort of Chinese patients with Wilson's disease guides genetic diagnosis. Theranostics, 6, pp. 638-649. doi: 10.7150/thno.14596

5. Dong Y., Shi S.S., Chen S., Ni W., Zhu M., Wu Z.Y. (2015) The discrepancy between the absence of copper deposition and the presence of neuronal damage in the brain of Atp7b(-/-) mice. Metallomics, 7, pp. 283-288. doi: 10.1039/C4MT00242C.

6. Gerosa C., Fanni D., Congiu T., Piras M., Cau F., Moi M., Faa G. (2019) Liver pathology in Wilson's disease: From copper overload to cirrhosis. J Inorg Biochem., 193, pp. 106-111. doi: 10.1016/j.jinorgbio.2019.01.008

7. Hedera P. (2017) Update on the clinical management of Wilson's disease. App/ Clin Genet., 10, pp. 9-19. doi: 10.2147/TACG.S79121

8. Piotr Socha, Wojciech Janczyk, Anil Dhavan (2018) Wilson's disease in children: a position paper by the hepatology committee of the European society for pediatric gastroenterology, hepatology and nutrition. JPGN, vol. 66, no 2, doi: 10.1097/MPG.0000000000001787

9. Pfeiffenberger J., Lohse C.M., Gotthardt D., Rupp C., Weiler M., Teufel U., Weiss K.H., Gauss A. (2019) Long-term evaluation of urinary copper excretion and non-caeruloplasmin associated copper in Wilson disease patients under medical treatment. J Inherit Metab Dis., 42 (2), pp. $371-$ 380. doi: $10.1002 /$ jimd.12046

10. Poujois A., Trocello J.M., Djebrani-Oussedik N., Poupon J., Collet C., Girardot-Tinant N., Sobesky R., Habès D., Debray D., Vanlemmens C., Fluchère F., Ory-Magne F., Labreuche J., Preda C., Woimant F. (2017) Exchangeable copper: a reflection of the neurological severity in Wilson's disease. Eur J Neurol., 24 (1), pp. 154-160. doi: 10.1111/ene.13171.

11. Richards S., Aziz N., Bale S., Bick D., Das S., Gastier-Foster J. (2015) Standards, guidelines for the interpretation of sequence variants. A joint consensus recommendation of the American College of Medical Genetics and Genomics and the Association for Molecular Pathology. Genet Med., 17, pp. 405-424. doi: 10.1038/gim.2015.30

12. Ryan A., Nevitt S.J., Tuohy O., Cook P. (2019) Biomarkers for diagnosis of Wilson's disease. Cochrane Database Syst Rev., 11: CD012267. doi: 10.1002/14651858.CD012267.

13. Strum E., Piersma F.E., Tanner M.S., Socha P., Shneider B.L. (2016) Controversies and variations in diagnosing and treating children with Wilson disease: Results of an international survey. J Pediatrics Gastroenterol Nutr., 63 (1), p. 82 doi: 10.1097/mpg.0000000000001102

14. Poujois A., Woimant F. (2018) Clin. Wilson's disease: A 2017 update. Res Hepatol Gastroenterol., 42 (6), pp. 512-520. doi: 10.1016/j.clinre.2018.03.007.

15. Xie J.J., Wu Z.Y. (2017) Wilson's Disease in China. Neurosci Bull., 33, pp. 323-330. doi: 10.1007/s12264-017-0107-4

16. Zhu M., Dong Y., Ni W., Wu Z.Y. (2015) Defective roles of ATP7B missense mutations in cellular copper tolerance and copper excretion. Mol Cell Neurosci., 67, pp. 31-36. doi: 10.1016/j.mcn.2015.05.005

Submitted/Подана: 26.03.2021

Accepted/Принята: 20.09.2021

Contacts/Контакты: vorobienko@gmail.com 